\title{
PEMBERDAYAAN POTENSI TENUN MENUJU MASYARAKAT KERJA, MANDIRI, DAN SEJAHTERA DI DESA SIDOMULYO, KECAMATAN SELOREJO, KABUPATEN BLITAR
}

\author{
Oleh: \\ Eti Setiawati ${ }^{1}$, Putri Kumala Dewi ${ }^{2}$, Dany Ardhian ${ }^{3}$, Fatmawati', Wahyu Widodo ${ }^{5}$ \\ 1,2,3,4,5 Universitas Brawijaya \\ ety64@ub.ac.id
}

\begin{abstract}
Abstrak
Di Desa Sidomulyo terdapat industri kerajinan tenun yang berpotensi Internasional. Industri tenun ini adalah industri tenun AJZ, milik Ibu Asih Tri Tanti, seorang purna TKW (Tenaga Kerja Wanita). Menurut hasil wawancara dengan Ibu Asih Tri Tanti pada tanggal 13 April 2017, diketahui bahwa keterampilan menenun yang dimilikinya saat ini diperoleh selama bekerja sebagai TKW di Brunei Darussalam. Kemudian tahun 2013, pengrajin ini kembali ke Desa Sidomulyo untuk mengembangkan potensi kerajinan tenun di desanya, Namun, terdapat banyak kendala. Akhirnya Sejak tahun 2013 hingga 2017 bu Asih bekerja sama dengan pengusaha dari Kesultanan Brunei Darussalam dan telah dikontrak selama 10 tahun oleh negara ini. Setiap lembarnya, kain tenun ini dijual Rp 5.000.000. Potensi bu Asih sangat berpeluang untuk dikembangkan. Pengembangan kerajinan tersebut dapat membuka kesempatan kerja dari warga sekitar dan tentu meningkatkan kesejahteraan masyarakat, khususnya perempuan rentan dan perempuan penyandan disabilitas. Pengabdian ini bertujuan untuk(1) meningkatkan ketersediaan sumber daya manusia dari kelompok difabel dan perempuan rentan, (2) membentuk pola pikir masyarakat yang memiliki karakter kemandirian, (3) membentuk koordinasi antara pemerintah dengan masyarakat terkait pengembangan potensi tenun, dan (4) memberikan wadah bagi warga difabel yang tergabung dalam PPDI untuk mengembangkan keterampilannya. Metode pelaksanaan dilaksanakan melalui kegiatan Seminar dan Pelatihan menenun bagi perempuan rentan dan perempuan penyandang disabilitas. Hasilnya menunjukkan bahwa kegiatan pengabdian masyarakat Universitas Brawijaya dalam pelatihan menenun ini mampu (1) meningkatkan Sumber Daya Manusia (SDM) (difabel dan perempuan rentan) di Desa Sidomulyo Kabupaten Blitar, (2) meningkatkan pola pikir masyarakat yang memiliki karakter kemandirian, dan (3) mampu mengubah pola pikir masyarakat setempat untuk tidak malu ikut bekerja menenun di tetangga sendiri.
\end{abstract}

Kata Kunci: pemberdayaan, potensi tenun, masyarakat, desa Sidomulyo

\begin{abstract}
In Sidomulyo Village there is a weaving craft industry that has the potential to be international. This weaving industry is AJZ's weaving industry, owned by Mrs. Asih Tri Tanti, a full-time female worker. According to the results of an interview with Ms. Asih Tri Tanti on April 13, 2017, it is known that her weaving skills are currently acquired while working as a migrant worker in Brunei Darussalam. Then in 2013, this craftsman returned to Sidomulyo Village to develop the potential of weaving craft in his village. However, there were many obstacles. Finally, from 2013 to 2017, Bu Asih worked with businessmen from the Sultanate of Brunei Darussalam and had been contracted for 10 years by this country. Each sheet, this woven fabric is sold at Rp. 5,000,000. The potential of Asih bu is very likely to be developed. The development of these handicrafts can open employment opportunities from local residents and certainly improve the welfare of the community, especially vulnerable women and women with disability. This service aims to (1) increase the availability of human resources from diffable groups and vulnerable women, (2) shape the mindset of the people who have the character of independence, (3) establish coordination between the government and the community regarding the development of weaving potential, and (4) provide a place for people with disabilities who are members of PPDI to develop their skills. The method of implementation is carried out through seminars and weaving training for vulnerable women and women with disabilities. The results show that UB's community service activities in this weaving training are able to (1) improve Human Resources (HR) (disabled and vulnerable women) in Sidomulyo Village, Blitar Regency, (2) improve the mindset of the people who have the character of independence, and (3) able to change the mindset of the local community to not be ashamed to work in weaving in their own neighbors.
\end{abstract}

Keywords: empowerment, weaving potency, society, desa Sidomulyo 


\section{PENDAHULUAN}

Desa Sidomulyo ini memiliki industri kerajinan tenun yang berpotensi internasional. Industri tenun ini adalah industri tenun AJZ, milik Ibu Asih Tri Tanti, seorang purna TKW (Tenaga Kerja Wanita). Menurut hasil wawancara dengan Ibu Asih Tri Tanti pada tanggal 13 April 2017, diketahui bahwa keterampilan menenun yang dimilikinya saat ini diperoleh selama bekerja sebagai TKW di Brunei Darussalam. Kemudian tahun 2013, pengrajin ini kembali ke Desa Sidomulyo untuk mengembangkan potensi kerajinan tenun di desanya. Sejak tahun 2013 hingga 2017, industri ini telah mengirimkan produk kain-kain tenun secara rutin ke Kesultanan Brunei Darussalam karena telah dikontrak selama 10 tahun oleh negara ini. Setiap lembarnya, kain tenun ini dijual Rp 5.000.000. Adapun desainnya telah ditentukan oleh negara tersebut.

Menurut hasil wawancara dan observasi tanggal 13 April 2017, juga diperoleh data bahwa hingga saat ini, Ibu Asih Tri Tanti memiliki 9 karyawan dan seluruhnya juga purna TKW. Para karyawan ini adalah warga Desa Sidomulyo yang pada awalnya tidak memiliki keterampilan menenun sama sekali. Dengan keuletan, Ibu Asih Tri Tanti melatih mereka secara intensif selama satu bulan. Setelah terampil, mereka dipekerjakan di tempat usaha ini dan menerima gaji mulai $\mathrm{Rp}$ 600.000 hingga $\mathrm{Rp} 2.500 .000$ bergantung tingkat kerumitan motif yang dibuat. Setiap bulan, dengan satu alat pemintal tenun, seorang karyawan hanya mampu memproduksi selembar kain tenun berukuran 2 meter. Sementara tugas pemilik adalah membuat desain dan finisihing.

Sementara itu, permintaan pasar lokal yang datang ke tempat usaha ini juga sangat pesat. Pesanan dari pasar lokal umumnya berupa lembaran kain tenun dan bagian selop sandal klompen. Pesanan kain tenun akan semakin ramai pada musim pernikahan dan menjelang hari besar keagamaan. Sementara itu, untuk bagian selop sandal klompen dipesan rutin oleh pengrajin sandal klompen dari Desa Toyomarto, Kecamatan Singosari, Kabupaten Malang. Bagian selop ini dibuat dari kain tenun perca. Namun, karena keterbatasan SDM, akhirnya jumlah yang bisa dipenuhi hanya terbatas. Bahkan tidak bisa dipenuhi.

Menurut hasil observasi pada tanggal 13 April 2017, industri ini hanya memiliki 13 alat pemintal terdiri atas 3 alat untuk pembuatan desain dan 10 alat untuk produksi. Mengenai jumlah SDM, pengrajin ini telah berusaha mencari tambahan tenaga kerja perempuan dari warga sekitar. Namun, terkendala oleh pola pikir dan lemahnya karakter kemandirian perempuan-perempuan desa setempat. Menurut Kemendiknas (2010) indikator karakter kemandirian adalah sikap dan perilaku yang tidak mudah bergantung pada orang lain dalam menyelesaikan tugastugas. Mereka memiliki pemikiran segan bekerja di tetangga sendiri, menganggap pekerjaan menenun sangat rumit, serta memiliki pandangan lebih baik bekerja sebagai buruh tani, pencari rumput untuk pakan ternak, atau pembantu rumah tangga di daerah lain. Sementara itu,untuk alat pemintal, sebenarnya sejak tahun 2014, pengrajin ini sudah pernah mengajukan proposal ke Pemerintah Daerah dan disetujui oleh Bupati Blitar, tetapi menurut perangkat desa disposisi di tingkat bawah terkendala oleh UU Desa. Bahkan Dinas Perdagangan dan Koperasi yang diharapkan mendukung potensi kerajinan tenun ini nyatanya pernah datang hanya untuk menyelenggarakan kegiatan workshop menenun selama dua hari untuk sekadar mengambil foto-foto kegiatan.

Pengrajin berharap dengan memberdayakan perempuan-perempuan Desa Sidomulyo untuk dilatih menjadi tenaga terampil, dapat memberdayakan potensi tenun Desa Sidomulyo, Kecamatan Selorejo, Kabupaten Blitar. Sasaran awal program ini adalah perempuan-perempuan rentan, yaitu perempuan yang rawan terhadap krisis, tidak memiliki akses ekonomi, dan tidak memiliki perlindungan sosial. Sasaran kedua adalah perempuan-perempuan Desa Sidomulyo anggota PPDI (Perkumpulan Penyandang Disabilitas Indonesia) Kabupaten Blitar.

$\mathrm{Hal}$ itu, sejalan dengan hasil wawancara pada tanggal 20 April 2017 dengan Bapak Achmad Sugik, Ketua PPDI (Perkumpulan Penyandang Disabilitas Indonesia) Kabupaten Blitar bahwa saat ini PPDI memiliki anggota sebanyak 760 orang. Di antaranya menurut Data BPS Kabupaten Blitar (2016:78-79) penyandang disabilitas tersebut adalah warga Desa Sidomulyo yang terdiri atas 15 tuli, 5 bisu, 5 tuli bisu, 4 tuna daksa, 9 tuna grahita, 1 tuna laras, dan 1 cacat eks kusta. Untuk 29 orang penyandang disabilitas tuli, bisu, tuli bisu, dan tuna daksa sangat membutuhkan wadah untuk mengembangkan keterampilannya secara mandiri setelah menempuh pelatihan secara gratis di bawah PPDI. Berdasarkan analisis 
situasi tersebut, kegiatan pengabdian kepada masyarakat dalam bentuk pemberdayaan potensi tenun serta pemberdayaan perempuan-perempuan rentan dan anggota PPDI Desa Sidomulyo untuk diberikan pelatihan menenun sangat perlu untuk segera dilaksanakan.

\section{METODE PELAKSANAAN KEGIATAN}

Kegiatan pemberdayaan potensi tenun dilaksanakan berdasarkan permasalahan yang ditemukan saat analisis situasi. Adapun empat fokus permasalahan tersebut antara lain: (1) tidak seimbangnya rasio antara ketersediaan sumber daya manusia dengan produk tenun yang dihasilkan untuk memenuhi kebutuhan di pasaran, (2) pola pikir masyarakat yang kurang memiliki karakter kemandirian, (3) kurang terbentuknya koordinasi antara pemerintah dengan masyarakat terkait pengembangan potensi tenun, dan (4) kurangnya wadah bagi warga difabel yang tergabung dalam PPDI untuk mengembangkan keterampilannya.

Berdasarkan permasalahan tersebut, berikut relialisasi metode pelaksanaan kegiatan pengabdian masyarakat yang dijalankan oleh tim.

\section{(1) Seminar}

Seminar diisi oleh Fatmawati, M.Sn, pakar desain seni kriya, Ibu Asih Tri Tanti sebagai pemilik industri tenun, dan Drs. Rully Wahyu P., ME selaku Camat Selorejo. Dalam hal ini, pakar desain menjelaskan estetika dalam seni kriya, khususnya tenun. Kemudian alat, teknik menenun, motif, dan pangsa pasar disampaikan oleh Ibu Asih Tri Tanti. Sementara itu, Bapak Camat Selorejo menyampaikan tentang potensi tenun Desa Sidomulyo sebagai penunjang perekonomian rakyat di Blitar.

\section{(2) Pelatihan}

Pelatihan diselenggarakan untuk memberi keterampilan yang cukup sebagai modal awal kepada para calon pengrajin kain tenun. Berikut tahapan-tahapan yang dijadwalkan.

Tahapan pelatihan:

Pertama : Seminar kepada peserta dari warga Desa Sidomulyo yang telah ditunjuk dan anggota PPDI yang telah ditugaskan. Dilanjutkan dengan pembagian kelompok dan praktik menenun.
Kedua : Pelatihan menenun oleh Tim Bu Asih Selama 1 bulan dengan perician:

Minggu I: seminar, pembagian kelompok, pengenalan alat tenun, pembuatan desain, dan kegiatan menenun

kelompok I (motif sederhana). Minggu II: pengenalan alat tenun, pembuatan desain, dan kegiatan menenun kelompok II (motif cengkeh). Minggu III : pengenalan alat tenun, pembuatan desain, dan kegiatan menenun kelompok III (motif kenanga).

Adapun kegiatan evaluasi hasil kerja dilakukan pada masingmasing kelompok pada setiap akhir minggu dengan mempertimbangkan kesesuain desain dengan produk, meliputi bentuk secara keseluruhan, komposisi motif, warna, dan finishing yang terdiri atas hasil akhir dan kemasan.

Ketiga : magang di tempat Bu Asih untuk belajar secara langsung terkait teknik menenun. Peserta yang dapat magang di tempat Bu Asih adalah yang memenuhi hasil karya dalam kualifikasi sangat baik menurut hasil evaluasi kegiatan. Kegiatan magang dilaksanakan di minggu IV.

\section{(3) Khalayak Sasaran}

Sasaran utama dalam penelitian ini adalah kelompok perempuan rentan dan para penyandang difabel anggota PPDI Kabupaten Blitar. Penyerapan tenaga kerja dengan memberdayakan perempuanperempuan rentan dan anggota PPDI Desa Sidomulyo. Target luaran dari kegiatan ini adalah menghasilkan lima tenaga terampil, khususnya perempuan rentan dan lima tenaga terampil anggota PPDI dari Desa Sidomulyo. Perempuan rentan yang dimaksud di sini adalah perempuan yang rawan terhadap krisis, tidak memiliki akses ekonomi, dan tidak memiliki perlindungan sosial.

Kegiatan pelatihan menenun ini diharapkan dapat memberikan bekal keterampilan menenun terhadap masyarakat desa sekitar dan anggota PPDI, meningkatkan karakter kemandirian masyarakat, menambah jumlah SDM, memberikan wadah peningkatan keterempilan bagi kaum difabel, serta meningkatkan produksi tenun, potensi tenun untuk perkembangan desa, dan taraf 
perekonomian masyarakat Desa Sidomulyo, Kecamatan Selorejo, Kabupaten Blitar.

\section{HASIL DAN LUARAN YANG DICAPAI}

Kegiatan pelatihan menenun yang terdapat di Desa Sidomulyo ini dilaksanakan mulai tanggal 7 Agustus 2017 hingga tanggal 28 Agustus 2017. Kegiatan tersebut dilaksanakan mulai pukul 08.00 sampai pukul 16.00 WIB. Pada agenda kegiatan pelatihan pembuatan tenun ini dibagi menjadi empat minggu. Minggu pertama,hari pertama adalah seminar yang diisi oleh narasumber Fatmawati, M.Sn, Ibu Asih Tri Tanti, dan Drs. Rully Wahyu P., ME. Dilanjutkan dengan pelatihan menenun motif sederhana oleh kelompok I yang terdiri atas tiga peserta. Minggu kedua adalah pelatihan menenun motif lokal (cengkeh) oleh kelompok II yang terdiri atas empat peserta difabel, anggota PPDI. Minggu ketiga adalah pelatihan menenun kelompok III dengan motif lokal (kenanga) yang diikuti oleh 3 peserta terdiri atas 2 peserta warga Desa Sidomulyo dan 1 peserta difabel, anggota PPDI. Minggu IV adalah magang untuk peserta yang setelah dievaluasi, hasil karyanya berada pada kualifikasi sangat baik.

Pada minggu pertama, hari pertama, yaitu tanggal 7 Agustus 2017, kegiatan seminar dimulai pukul 09.15 sampai pukul $13.00 \mathrm{WIB}$, yang dihadiri oleh Drs. Rully Wahyu P., ME (Camat Selorejo), Bapak Wakhid Basuki, S.Sos, Kepala Desa Sidomulyo, Bapak Untung (perwakilan PPDI (Persatuan Penyandang Disabilitas Indonesia, Kab. Blitar), Bapak Eko dan Ibu Asih (Pemilik usaha tenun), peserta pelatihan berjumlah 15 orang, karyawan usaha tenun, serta Bapak/lbu dosen Universitas Brawijaya dan 5 mahasiswa Universitas Brawijaya Malang. Pukul 09.15 sampai 09.50 WIB adalah laporan kegiatan oleh Ketua Pengabdian Masyarakat, Dr. Eti Setiawati, M.Pd. Dilanjutkan dengan sambutan Camat Selorejo, instruktur pelatihan tenun, dan perwakilan PPDI Kab. Blitar. Acara selanjutnya adalah penyampaian materi oleh Fatmawati, M.Sn selaku pakar seni kriya. Beliau menyampaikan tentang estetika dalam seni kriya, khususnya tenun. Kemudian disambung dengan narasumber yang kedua yaitu Ibu Asih Tri Tanti yang dibantu oleh Bapak Eko menjelaskan tentang alat, teknik menenun, motif, dan pangsa pasar. Sementara itu, Bapak Camat Selorejo menyampaikan tentang potensi tenun Desa Sidomulyo sebagai penunjang perekonomian rakyat di Blitar.

Kegiatan dilanjutkan dengan tanya jawab dan pembagian nama-nama kelompok pada setiap minggu. Seluruh peserta diberikan instruktuksi oleh Ibu Asih dan karyawankaryawannya untuk mengenal alat serta bahan menenun. Selain itu, seluruh peserta juga diberikan kesempatan mencoba menenun kain polos yang telah disediakan Ibu Asih. Saat para peserta mengenal alat dan bahan tenun, mereka tertarik untuk mencoba untuk menenun dan didampingi oleh instruktur dan karyawan usaha tenun ini. Namun, pelatihan difokuskan ke tiga peserta dari kelompok I, yaitu Ibu Tunik Astutik, Ibu Ernawati, dan Ibu Devi Triana. Ketiga peserta ini termasuk dalam perempuan-perempuan rentan yang berasal dari Desa Sidomulyo.

Hari berikutnya, yaitu tanggal 8-11 Agustus 2017, tiga orang peserta dari kelompok I ini mulai mandiri menenun motif sederhana. Pada tanggal 11 Agustus 2017, tim yang bertugas datang langsung untuk mengamati dan mengevaluasi kinerja ketiga orang peserta ini antara lain : Wahyu Widodo, M.Hum, Choiridah Ayu S. N., Octa Dwi Saputra Wijaya, dan M. Zacky Mubarok. Dipilihnya hari terakhir sebagai hari evaluasi kegiatan pelatihan kelompok I adalah untuk mengetahui hasil kinerja menenun para peserta dan tingkat ketercapaiannya. Untuk evaluasi hari kedua hingga keempat dibantu oleh instruktur. Hasil dari kegiatan pelatihan ini secara umum dapat dikatakan berhasil. Hal tersebut dapat dilihat dari proses pembuatan dapat dijabarkan sebagai berikut.

Tabel 2 Rekapitulasi Hasil Pelatihan Pembuatan Kain Tenun

\begin{tabular}{clcc}
\hline No. & \multicolumn{1}{c}{ Nama Peserta } & Tenun Kain Polos & $\begin{array}{c}\text { Tenun Kain Motif } \\
\text { Sederhana }\end{array}$ \\
\hline 1. & Ibu Tunik Astutik & $12 \mathrm{~cm}$ & $30 \mathrm{~cm}$ \\
\hline 2. & Ibu Ernawati & $13 \mathrm{~cm}$ & $50 \mathrm{~cm}$ \\
\hline 3. & Ibu Devi Triana & $11 \mathrm{~cm}$ & $40 \mathrm{~cm}$ \\
\hline
\end{tabular}


Berdasarkan data yang terdapat pada tabel 2 dapat dikatakan bahwa proses pembuatan tenun oleh ketiga peserta pelatihan memperoleh hasil yang baik. Hal tersebut dapat terlihat pada proses pembuatan tenun kain polos oleh ketiga peserta pelatihan, meliputi Ibu Tunik Astutik memperoleh hasil $12 \mathrm{~cm}$, lbu Ernawati memperoleh hasil $13 \mathrm{~cm}$, dan Ibu Devi Triana memperoleh hasil $11 \mathrm{~cm}$. Sementara itu, proses pembuatan tenun kain motif sederhana mengalami peningkatan yang signifikan. Peningkatan tersebut dapat terlihat pada hasil yang diperoleh Ibu Tunik Astutik yaitu $30 \mathrm{~cm}$, Ibu Ernawati mengalami peningkatan menjadi $50 \mathrm{~cm}$, dan Ibu Devi Triani memperoleh hasil $40 \mathrm{~cm}$. Hasil yang diperoleh ketiga peserta pelatihan tenun ini, sama-sama memulai tenunan dari tenunan kain polos kemudian dilanjutkan dengan tenunan kain yang bermotif sehingga setiap peserta menghasilkan tenunan yang berbeda-beda. Perbedaan hasil tenunan setiap peserta bergantung dari kekuatan kerja tangan dan kaki untuk menjalankan mesin tenun sehingga menghasilkan kain tenun yang penyelesainnya berbeda-beda. Berikut adalah gambar kegiatan menenun minggu I dan hasilnya.

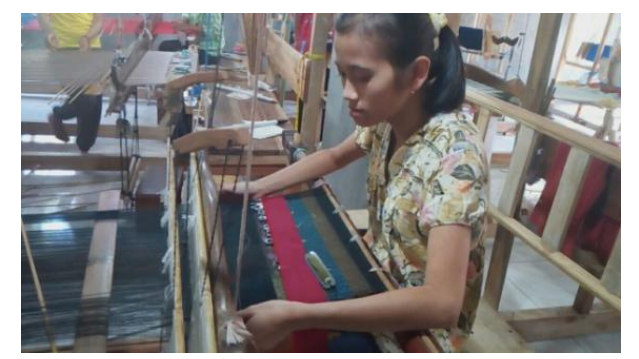

Gambar 2 Kegiatan Menenun Minggu I dan Hasilnya
Berdasarkan gambar 2 di atas diketahui bahwa para peserta pelatihan minggu I ini telah berproses untuk menenun motif sederhana. Sebagai pemula, menurut lbu Asih Tri Tanti selaku instruktur, keterampilan para peserta ini berada pada kualifikasi baik. Hal itu disebabkan oleh para peserta ini sebelumnya tidak memiliki keahlian menenun dan dalam pelatihan ini mampu menenun motif cengkeh hanya dalam waktu 5 hari.

Kegiatan pelatihan minggu kedua berlangsung tanggal 12-16 Agustus 2018. Tim yang bertugas mengevaluasi di minggu kedua ini terdiri atas Dr. Eti Setiawati, M.Pd, Putri Kumala Dewi, M.Pd, Fatmawati, M.Sn, Dany Ardhian, M.Hum, dan Aulia Mayasari. Evaluasi dilakukan tanggal 16 Agustus 2017. Dipilihnya hari terakhir sebagai hari evaluasi kegiatan pelatihan kelompok II adalah untuk mengetahui hasil kinerja menenun para peserta dan tingkat ketercapaiannya. Untuk evaluasi hari pertama hingga keempat dibantu oleh instruktur. Peserta pelatihan pada minggu kedua ini seluruhnya adalah anggota PPDI. Jumlah peserta 4 orang yaitu Ibu Estiningsih, Ibu Rasmiati, Ibu Fitri A., dan Ibu Winarsih. Keempat peserta pelatihan tenun ini merupakan penyandang disabilitas yang memiliki semangat kerja dan mengubah nasib menjadi lebih baik dibandingkan sebelumnya. Selain itu, mereka memerlukan wadah untuk pengembangan keterampilannya.Asal mereka dari Desa Sidomulyo dan Kecamatan Kesamben.

Kain tenun yang dihasilkan oleh keempat peserta penyandang disabilitas pada pertemuan ketiga ini secara umum dapat dikatakan berhasil. Keberhasilan tersebut dapat dilihat dari proses pembuatan dapat dijabarkan sebagai berikut.

Tabel 3 Rekapitulasi Hasil Pelatihan Pembuatan Kain Tenun

\begin{tabular}{clcc}
\hline No. & \multicolumn{1}{c}{ Nama Peserta } & Tenun Kain Polos & Tenun Kain Motif Cengkeh \\
\hline 1. & lbu Estiningsih & $14 \mathrm{~cm}$ & $32 \mathrm{~cm}$ \\
\hline 2. & Ibu Rasmiati & $13 \mathrm{~cm}$ & $44 \mathrm{~cm}$ \\
\hline 3. & Ibu Fitri A & $16 \mathrm{~cm}$ & $56 \mathrm{~cm}$ \\
\hline 4. & lbu Winarsih & $11 \mathrm{~cm}$ & $53 \mathrm{~cm}$ \\
\hline
\end{tabular}

Berdasarkan data yang terdapat dalam tabel 3 dapat dikatakan bahwa hasil yang diperoleh dari kegiatan pelatihan keempat penenun penyandang disabilitas ini lebih baik dan lebih rapi dibandingkan hasil tenunan warga yang normal dengan taraf pembelajaran serta waktu yang sama. Bentuk kerapian dan ukuran kain yang diperoleh lebih panjang dibandingkan warga yang normal pada pertemuan kedua. Hal tersebut dapat terlihat pada proses pembuatan tenun kain polos oleh keempat peserta penyandang disabilitas, yang meliputi lbu Estiningsih dengan memperoleh hasil $14 \mathrm{~cm}$, Ibu Rasmiati memperoleh hasil $13 \mathrm{~cm}$, lbu Fitri yang memperoleh hasil $16 \mathrm{~cm}$, sedangkan lbu Winarsih memperoleh hasil $11 \mathrm{~cm}$. Sementara itu, untuk proses pembuatan tenun kain dengan motif cengkeh mengalami peningkatan yang signifikan 
dibandingkan pembuatan tenun kain tenun polos. Peningkatan tersebut dapat terlihat pada hasil yang diperoleh Ibu Estiningsih yang memperoleh hasil $32 \mathrm{~cm}$, Ibu Rasmiati memperoleh hasil $44 \mathrm{~cm}$, Ibu Fitri yang memperoleh hasil $56 \mathrm{~cm}$, dan Ibu Winarsih memperoleh hasil $53 \mathrm{~cm}$. Meskipun keempat peserta merupakan penyandang disabilitas, namun keempat peserta ini dapat menghasilkan kain tenun yang bagus dan rapi tetapi keempat peserta ini memiliki kendala selama menjalani kegiatan pelatihan menenun ini, yaitu keempat peserta kesulitan dalam mengangkat motif cengkeh di kain yang telah disediakan oleh instruktur. Hal tersebut disebabkan dalam kegiatan menenun memerlukan kekuatan tangan dan kekuatan kaki dalam menjalankan mesin tenun sehingga mampu menghasilkan kain tenun yang lebih bagus. Karya keempat peserta pelatihan minggu kedua adalah sebagai berikut.

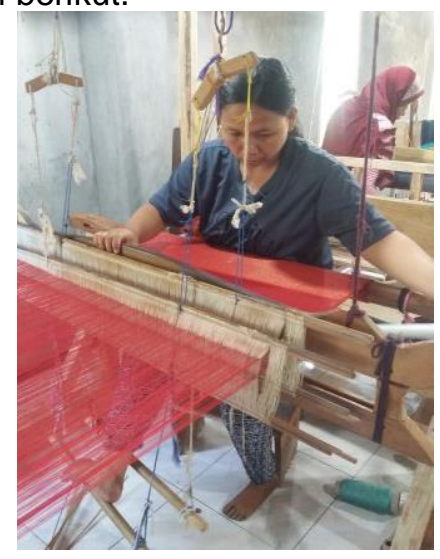

Gambar 3 Kegiatan Menenun Peserta Pelatihan dari Anggota PPDI dan Hasil Karyanya

Berdasarkan gambar 3 di atas diketahui bahwa para anggota PPDI yang menjadi peserta pelatihan minggu II ini telah berproses untuk menenun motif lokal Desa Sidomulyo, yaitu cengkeh. Sebagai pemula, menurut Ibu Asih Tri Tanti selaku instruktur, keterampilan para peserta ini berada pada kualifikasi baik. Hal itu disebabkan oleh para peserta ini sebelumnya tidak memiliki keahlian menenun dan dalam pelatihan ini mampu menenun motif cengkeh hanya dalam waktu 5 hari.

Kegiatan pelatihan minggu III dilaksanakan tanggal 17-21 Agustus 2017. Agendanya adalah menenun motif kenanga. Kegiatan ini diikuti oleh 3 peserta terdiri atas 2 peserta warga Desa Sidomulyo dan 1 peserta difabel, anggota PPDI. Nama-nama peserta adalah lbu Sukma, Ibu Lestari, dan Ibu Lilik S. Mereka berasal dari Desa Sidomulyo.Hasil dari kegiatan pelatihan pembuatan tenun ini secara umum dapat dikatakan berhasil. Hal tersebut dapat dilihat dari proses pembuatan dapat dijabarkan sebagai berikut.

Tabel 3 Rekapitulasi Hasil Pelatihan Pembuatan Kain Tenun

\begin{tabular}{clcc}
\hline No. & \multicolumn{1}{c}{ Nama Peserta } & Tenun Kain Polos & $\begin{array}{c}\text { Tenun Kain Motif } \\
\text { Kenanga }\end{array}$ \\
\hline 1. & Ibu Sukma & $13 \mathrm{~cm}$ & $50 \mathrm{~cm}$ \\
\hline 2. & lbu Lestari & $11 \mathrm{~cm}$ & $30 \mathrm{~cm}$ \\
\hline 3. & Ibu Lilik S & $13 \mathrm{~cm}$ & $40 \mathrm{~cm}$ \\
\hline
\end{tabular}

Berdasarkan data pada tabel 3 dapat dikatakan bahwa proses pembuatan tenun oleh ketiga peserta pelatihan memperoleh hasil yang baik. Hal tersebut dapat terlihat pada proses pembuatan tenun kain polos oleh ketiga peserta pelatihan, meliputi lbu Sukma memperoleh hasil $13 \mathrm{~cm}$, Ibu Lestari memperoleh hasil $11 \mathrm{~cm}$, dan Ibu Lilik memperoleh hasil $13 \mathrm{~cm}$. Sementara itu, proses pembuatan tenun kain motif kenanga mengalami peningkatan yang signifikan, padahal proses pembuatan tenun kain motif kenanga lebih rumit dibandingkan pembuatan tenun kain polos. Peningkatan dapat terlihat pada hasil yang diperoleh lbu Sukma memperoleh hasil $50 \mathrm{~cm}$, Ibu Lestari memperoleh hasil $30 \mathrm{~cm}$, dan Ibu Lilik memperoleh hasil $40 \mathrm{~cm}$. Hasil yang diperoleh ketiga peserta pelatihan tenun ini, sama-sama memulai tenunan dari tenun kain polos kemudian dilanjutkan dengan tenunan kain yang bermotif kenanga sehingga setiap peserta menghasilkan tenunan yang berbeda-beda.

Adapun, pada minggu ketiga ini, terdapat satu peserta penyandang disabilitas tangan sehingga hasil yang diperoleh tidak sama 
dengan hasil yang diperoleh warga yang normal. Hal tersebut disebabkan Ibu Lestari, penyandang disabilitas tangan sehingga kekuatan tangan dan kekuatan kakinya tidak seimbang. Padahal dalam kegiatan menenun kekuatan tangan dan kaki yang dibutuhkan untuk menjalankan mesin tenun sehingga menghasilkan kain tenun yang bagus. Kemudian, dilanjutkan dengan adanya proses pemotongan kain tenun yang telah dihasilkan oleh peserta pelatihan dari minggu pertama hingga ketiga.Berikut adalah gambar hasil kegiatan pelatihan minggu III.

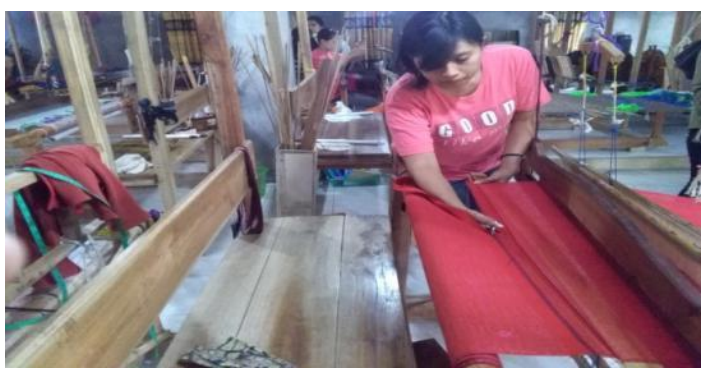

Gambar 4 Kegiatan dan Hasil Pelatihan Menenun Minggu III

Berdasarkan gambar 4 di atas dapat diketahui bahwa para peserta telah mampu menyelesaikan tenunnya dengan motif kenanga. Motif tersebut merupakan motif lokal Desa Sidomulyo. Menurut Bu Asih ini merupakan hasil yang sangat baik untuk seorang pemula. Apalagi sebelumnya belum memiliki keterampilan menenun dan dihasilkan hanya dalam waktu 5 hari.

Pada minggu IV, peserta yang hasil karyanya menurut Ibu Asih berada pada kualifikasi sangat baik, diberikan kesempatan untuk magang di tempat $\mathrm{Bu}$ Asih.Hasilnya adalah terdapat dua orang peserta yang memiliki kesempatan magang di tempat usaha Bu Asih. Bahkan tidak menutup kemungkinan akan direkrut sebagai karyawan tetap Bu Asih.

\section{PEMBAHASAN LUARAN YANG DICAPAI}

Proses pembuatan kain tenun di Desa Sidomulyo, menurut lbu Asih yang merupakan pemilik usaha tenun sekaligus instruktur pelatihan tenun ini dimulai dari pengumpulan bahan, pemintalan benang, pemasangan benang pada mesin tenun, menenun, dan tahap akhir adalah pemotongan kain. Ibu Asih menggunakan bahan-bahan yang sebagian besar diimpor dari luar negeri dikarenakan kualitas bahan yang lebih bagus dibandingkan dengan bahan lokal. Bahan-bahan yang akan digunakan untuk menenun adalah benang tenun atau benang Lungsi (lusi) dengan berbagai warna. Adapun peralatan yang harus disiapkan yaitu mesin tenun, yang masih tradisional karena terbuat dari kayu.

Setelah semua alat dan bahan tersedia, kemudian dilanjutkan denganadanya proses pemasangan benang pada mesin tenun. Pemasangan benang dilakukan dengan cara memasang satu persatu benang sesuai motif yang akan dikerjakan sehingga proses ini memerlukan waktu sampai satu minggu, lamanya proses memasang benang juga bergantung pada tingkat kesulitan motif yang akan dikerjakan. Semakin sulit motif yang akan dibuat semakin lama waktu yang dibutuhkan dalam proses pemasangan benang ini. Para penenun penyandang disabilitas yang baru belajar pada mulanya akan dipasangkan benang sesuai motif yang akan dikerjakan oleh ibu Asih. Ibu Asih juga mengakui bahwa pemasangan dan pembuatan motif ini merupakan pekerjaan yang cukup rumit dan memerlukan ketelatenan dan kesabaran. Namun, untuk kedepannya bu Asih berharap para penenun penyandang disabilitas ini dapat menguasai langka-langkah menenun ini dari awal sampai akhir.

Menurut Ibu Asih proses selanjutnya adalah proses menenun itu sendiri. Proses menenun dilakukan dengan menggunakan mesin tenun yang sudah terpasang benang Lungsi, kemudian ada satu benang yang dimasukan dicelah-celah benang yang sudah ditata sesuai dengan motif yang akan dikerjakan dari sisi kanan ke sisi kiri ataupun dari arah sebaliknya. Setelah benang sudah terpasang, ada balok kayu yang harus ditarik dengan kuat-kuat untuk memadatkan benang yang baru saja diselipkan. Proses itu dilakukan secara berulang-ulang sampai motif kain tenun yang diinginkan terbentuk. Kain tenunan yang dikerjakan di Blitar ini memiliki dua pilihan, yaitu tenun polos dan tenun motif. Untuk tenun motif ini biasanya mengerjakan motif Bunga Tabur dan Motif salur-salur. Kain tenun yang dihasilkan memiliki dua ukuran, yang pertama kain tenunan pendek dengan panjang $2 \mathrm{~m}$ danlebar 0,5 meter, yang kedua adalah tenunan lebar dengan panjang $2 \mathrm{~m}$ dan lebar 1 meter. Hasil kain tenun dapat dibuat sebagai sarung ataupun selendang. Proses menenun ini memerlukan waktu kurang lebih dua minggu sampai satu bulan, bergantung 
pada tingkat kesulitan motif dan ukuran kain tenun yang dikerjakan.

Hasil kain-kain tenun Blitar ini diekspor ke Brunei Darussalam dengan frekuensi pengiriman secara rutin satu bulan sekali karena telah dikontrak selama 10 tahun oleh negara ini. Proses pengerjaan yang rumit dan memakan waktu yang lama dalam membuat kain tenun ini sehingga memiliki nilai ekonomi yang sangat tinggi, yaitu untuk kain tenun dengan motif biasa dihargai kisaran Rp1.000.000-1.500.000, sedangkan untuk kain tenun dengan motif yang rumit dihargai kisaran Rp 5.000.000 atau lebih. Adapun desainnya telah ditentukan oleh negara tersebut. Harga tersebut sesuai dengan waktu dan kain tenun yang disilkan yang sangat bagus, rapi, dan indah.

Selain diekspor keluar negeri, jika ada waktu, usaha kain tenun Blitar lbu Asih ini juga melayani pemesanan dari dalam negeri. Kebanyakan pemesan meminta seperangkat kain untuk acara adat dan pernikahan yang akan dilakukan. Namun, harga yang dibandrol oleh lbu Asih untuk seperangkat kain tenun acara ini berkisar antara $\mathrm{Rp}$ 15.000.000 atau lebih bergantungjenis dan motif kain tenun yang dipesan.

Adapun kegiatan pengabdian masyarakat ini telah mampu memberikan bekal pengetahuan dan keterampilan menenun kepada para peserta, terlebih masyarakat dari kelompok perempuan-perempuan rentan yang berasal dari Desa Sidomulyo dan sekitarnya serta anggota PPDI (Persatuan Penyandang Disabilitas Indonesia). Dengan demikian, mampu memberikan wadah keterampilan bagi para penyandang disabilitas. Sementara itu, bagi perempuan-perempuan rentan di Desa Sidomulyo dan sekitarnya dapat mengubah mindset mereka bahwa menenun adalah kegiatan yang sangat rumit. $\mathrm{Hal}$ itu disebabkan oleh kenyatannya dalam waktu 5 hari, para peserta ini mampu menenun dengan motif sederhana hingga motif lokal, yaitu cengkeh dan kenanga.

Disisi lain, ditemukan beberapa kelebihan yang dimiliki oleh lima penyandang disabilitas ini adalah kain tenun yang dihasilkan oleh kelima penyandang disabilitas memiliki hasil yang lebih bagus dan lebih rapi dibandingkan kain tenun yang dihasilkan oleh warga yang normal. Selain itu, tenunan yang dihasilkan oleh penyandang disabilitas ini lebih panjang ukurannya dibandingkan warga yang normal.

Dengan adanya pendampingan dari instruktur menenun secara intensif dan dengan sabar memberikan arahan kepada para peserta sehingga peserta mampu menghasilkan kain tenun yang rapi, bagus dengan berbagai motif, serta kain yang dihasilkan oleh para peserta memiliki ukuran yang panjang. Para peserta mampu menghasilkan kain tenun yang berbeda-beda ukuran bergantung dari kapasitas kekuatan tangan dan kekuatan kaki dalam menggerakkan mesin tenun serta mengangkat motif ke dalam kain tenun yang telah disediakan. Selain itu, dengan adanya kegiatan pelatihan menenun ini juga mampu menimbulkan respons yang positif dari masyarakat sekitar Desa Sidomulyo sehingga mampu meningkatkan karakter kemandirian serta mengubah mindset atau pola pikir warga setempat untuk tidak malu ikut bekerja dengan tetangga sehingga tidak lagi ada rencana untuk mencari kerja ke luar negeri atau menjadi TKW kembali. Selain itu, juga dengan adanya pengabdian masyarakat ini diharapkan mampu menambah peningkatan produksi tenun, potensi tenun di dalam desa, serta mampu meningkatkan taraf hidup perekonomian masyarakat di Desa Sidomulyo, terlebih untuk masyarakat penyandang disabilitas. Terlebih dengan adanya dua orang peserta yang diberikan kesempatan magang oleh $\mathrm{Bu}$ Asih, diharapkann dapat meningkatkan pola pikir kemandirian secara ekonomi warga Desa Sidomulyo.

Keberhasilan dari adanya kegiatan pelatihan ini patut disyukuri karena adanya kerjasama yang baik dari seluruh elemen masyarakat Desa Sidomulyo, anggota PPDI, serta tim peneliti. Adapun faktor pendukung dari kegiatan ini adalah motivasi dari para peserta yaang tinggi dalam mengikuti serangkaian pelatihan menenun ini. Keberhasilan pelatihan menenun ini dapat terlihat bahwa seluruh peserta pelatihan menenun memiliki antusias yang baik. Selain itu, keberhasilan tersebut dapat terlihat pada saat kegiatan pelatihan ini berakhir, terdapat lebih kurang dua peserta pelatihan yang tetap meneruskan pekerjaan menenun di rumah usaha milik Ibu Asih. Ibu Asih berharap untuk kedepannya akan ada warga normal atau pun penyandang disabilitas di Desa Sidomulyo dan sekitarnya mau ikut serta dalam kegiatan pelatihan serta bergabung menjadi karyawan di usaha kain tenun ini sehingga mampu menjadikan usaha kerajinan tenun Blitar, khususnya di Desa Sidomulyo ini menjadi lebih maju dan dapat 
menjadikan Blitar menjadi Kota tenun yang makmur.

\section{SIMPULAN DAN SARAN}

\section{Simpulan}

Berdasarkan hasil penelitian dan pembahasan yang telah dipaparkan pada bab sebelumnya, dapat diambil simpulan sebagai berikut.

(1) Adanya kegiatan pengabdian masyarakat Universitas Brawijaya dalam pelatihan menenun ini mampu meningkatkan Sumber Daya Manusia (SDM) (difabel dan perempuan rentan) di Desa Sidomulyo Kabupaten Blitar. Hal tersebut terlihat dari kain tenun yang dihasilkan oleh kelima difabel memiliki hasil yang bagusberbagai motif dan lebih rapi dibandingkan kain tenun yang dihasilkan oleh peserta yang normal. Selainitu, tenunan yang dihasilkan oleh penyandang disabilitas ini lebih panjang ukurannya dibandingkan warga yang normal, sedangkan proses pembuatan kain tenun oleh kelima perempuan rentan memperoleh hasil yang baik. Hal tersebut dapat terlihat pada proses pembuatan tenun kain polos dan proses pembuatantenunkain motif sederhana mengalami peningkatan yang signifikan. Peserta sama-sama memulai tenunandari tenunan kain polos kemudian dilanjutkan dengan tenunan kain yang bermotif sehingga setiap peserta menghasilkan tenunan yang berbeda-beda. Perbedaan hasil tenunan setiap peserta bergantung dari kekuatan kerja tangan dan kaki untuk menjalankan mesin tenun sehingga menghasilkan kain tenun yang penyelesainnya berbeda-beda.

(2) Adanya kegiatan pengabdian masyarakat Universitas Brawijaya dalam pelatihan menenun ini mampu meningkatkan pola pikir masyarakat yang memiliki karakter kemandirian. Hal tersebut terlihat dari antusias dan semangat pesertadalam proses menenun yang mengandalkan dari kekuatan kerja tangan dan kaki untuk menjalankan mesin sehingga peserta tidak bergantung pada orang lain dalam menyelesaikan kain tenunannya. Selain itu, mampu mengubah pola pikir masyarakat setempat untuk tidak malu ikut bekerja menenun di tetangga sendiri.

(3) Keberhasilan kegiatan pelatihan menenun di Desa Sidomulyo Kabupaten Blitar merupakan bentuk kerjasama dari seluruh elemen masyarakat Desa Sidomulyo, anggota PPDI, serta tim peneliti dari Universitas Brawijaya dalam pengembangan potensi peserta difabel dan perempuan rentan. Hal tersebut terlihat dari keikutsertaan elemen masyarakat DesaSidomulyo, anggota PPDI, serta tim peneliti saat proses kegiatan pelatihan menenun berlangsung.

\section{Saran}

Warga Desa Sidomulyo, Kabupaten Blitar dan sekitarnya, baik penyandang disabilitas maupun perempuan rentan hendaknya bergabung menjadi karyawan di usaha kerajinan tenun songket AJZ, milik Ibu Asih. Dengan cara ini, mampu meningkatkan taraf hidup perekonomian masyarakat di Desa Sidomulyo, terlebih untuk masyarakat penyandang disabilitas, dan mampu menjadikan usaha kerajinan tenun Blitar, khususnya di Desa Sidomulyo menjadi lebih maju serta dapat menjadikan Kota Blitar menjadi Kota tenun songket yang makmur dansejahtera.

\section{DAFTAR PUSTAKA}

Badan Pusat Statistik Kabupaten Blitar. 2016. Kecamatan Selorejo dalam Angka 2016. Blitar: BPS.

Darmawan, Nunik. 2011. Lurik Tenun Tradisional Jawa. Yogyakarta: Dinas Kebudayaan Provinsi DIY.

Djoemana, S Nian. 2000. Lurik Garis-garis Bertuah The Magig Stripes. Jakarta: Penerbit Djambatan.

Geerts, Olifords.1992. Tafsir Kebudayaan. Yogyakarta: Penerbit Kanisius.

Kementerian Pendidikan Nasional. 2010. Pengembangan Pendidikan Budaya dan Karakter Bangsa. Jakarta: Badan Penelitian dan Pengembangan Pusat Kurikulum.

Martowikrido, Wahyono. 1994. Lurik Sejarah, Fungsi dan Artinya Bagi Masyarakat. Jakarta: Proyek Pembinaan Museum Nasional. 